RESEARCH ARTICLE

\title{
Chalcone Derivatives Activate and Desensitize the Transient Receptor Potential Ankyrin 1 Cation Channel, Subfamily A, Member 1 TRPA1 Ion Channel: Structure-Activity Relationships in vitro and Anti-nociceptive and Anti-inflammatory Activity in vivo
}

\author{
Aniello Schiano Moriello ${ }^{1}$, Livio Luongo ${ }^{2}$, Francesca Guida ${ }^{2}$, Mieahel S. Christodoulou ${ }^{3}$, \\ Dario Perdicchia ${ }^{3}$, Sabatino Maione ${ }^{2}$, Daniele Passarella ${ }^{3}$, Vincenzo Di Marzo ${ }^{1 *}$ and \\ Luciano De Petrocellis ${ }^{1 *}$ \\ ${ }^{I}$ Endocannabinoid Research Group, Institute of Biomolecular Chemistry, National Research Council, Via Campi \\ Flegrei 34, Comprensorio Olivetti, 80078 Pozzuoli, Naples, Italy; \\ ${ }^{2}$ Department of Experimental Medicine, Division of Pharmacology, Second University of Naples, 80138 Naples, Italy; \\ ${ }^{3}$ Department of Chemistry, University of Milan, Via Golgi 19, 20133 Milano, Italy
}

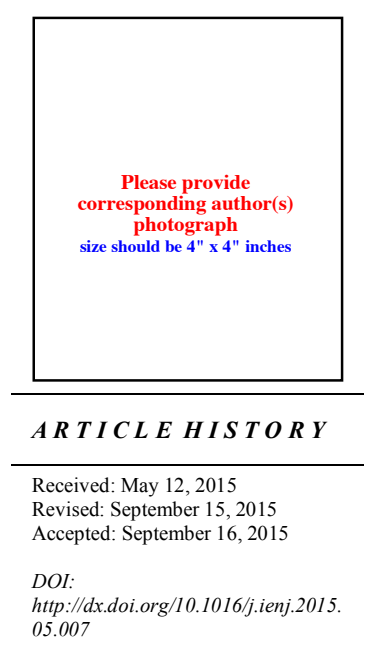

\begin{abstract}
Eleven compounds belonging to the chalcone family were tested for their ability to activate and subsequently desensitize the rat transient receptor potential ankyrin 1 cation channel, subfamily A, member 1 (TRPA1) in a heterologous expression system. Four of the tested compounds were more potent than the TRPA1 agonist mustard oil, and showed also a strong desensitizing effect. Some chalcone compounds were not pungent in the eye-wiping assay and quite remarkably inhibited in a long-lasting and dose-dependent manner the mustard oil-induced response in the formalin test. Chalcones can be considered as novel candidates for the development of anti-hyperalgesic preparations based on TRPA1 desensitization.
\end{abstract}

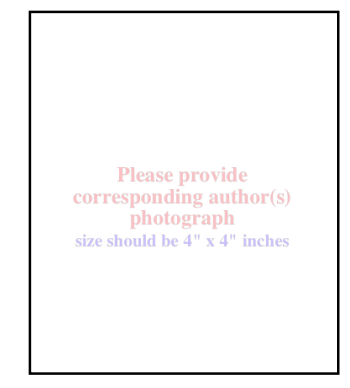

Keywords: Chalcones, eye wiping, neuropathic pain, pain, TRPA1.

\section{INTRODUCTION}

Chalcones are naturally-occurring compounds which display a wide range of biological properties. Chalcone (1,3diphenyl-2E-propene-1-one) is an open chain intermediate precursor in the synthesis of flavones [1]. It contains two aromatic rings connected by a $\alpha-\beta$-unsaturated ketone system [2]. The most important sources of chalcones are plant extracts, which are widely used in traditional Chinese

*Address correspondence to these authors at the Endocannabinoid Research Group, Institute of Biomolecular Chemistry, National Research Council, Via Campi Flegrei 34, Comprensorio Olivetti, 80078 Pozzuoli, Naples, Italy; Tel: (+39)-81-8675173; Fax: (+39)-81-8675340 - (+39)-81-8041770; E-mail: luciano.depetrocellis@icb.cnr.it; and Tel: (+39)-81-8675018, Fax: (+39)-81-8675340-. (+39)-81-8041770; E-mail: vdimarzo@icb.cnr.it
Medicine, although the potential uses of this family of compounds have not been fully explored [3].

Synthetic chalcones and chalcone derivatives show a wide range of biological activities with therapeutic interest [for reviews see 3, 4]. One of the most studied applications of these compounds is as anticancer agents $[5,6]$, and a series of chalcone derivatives with excellent antitumor activity have been patented [3]. Very interestingly, compounds bearing electron-withdrawing groups $\left(\mathrm{NO}_{2}\right.$ or $\mathrm{CN}$ ) on the ring near the $\alpha-\beta$-unsaturation of chalcones were the most potent [7]. Chalcone analogs bearing an additional $\alpha, \beta$-unsaturated arylketone were active against the resistant T-47D breast cancer cells [8]. The induction of apoptosis by intrinsic pathways, alterations in the cellular levels of Bcl-2 
family proteins, upregulation of p53 and PUMA, inhibition of nuclear factor- $\mathrm{\kappa B}(\mathrm{NF}-\mathrm{\kappa B})$ and Akt, and blockage of oxidative stress might represent possible mechanisms [9-14]. The role of some chalcones as anti-inflammatory agents is summarized in a comprehensive review [15]. Several pure chalcones have been approved for clinical use and tested in humans, and are well-tollerated [16].

Despite the impressive pharmacological potential of chalcones, their mechanism of action has not been fully clarified. The presence of a double bond in conjugation with a carbonyl group is believed to be responsible for the biological activities of chalcones. The $\alpha, \beta$-unsaturated carbonyl compounds, by being Michael acceptors and capable of trapping thiols, represent an important mechanism of bioactivity [17]. Nucleophilic cysteines and lysines located in the cytosolic N-terminus of the transient receptor potential ankyrin 1 cation channel, subfamily A, member 1 (TRPA1) undergo covalent attack by reactive electrophilic chemicals, leading to formation of Michael adducts and allosteric opening of the channel $[18,19]$. TRPA1 agonists such as allyl isothiocyanate (mustard oil, MO) and several $\alpha, \beta$-unsaturated aldehydes such as formaldehyde and its aqueous solution, formalin, directly activate TRPA1 and are widely used for testing analgesic compounds [20].

As the above data suggest that calchones might modulate TRPA1 activity we investigated 11 novel chalcone derivatives for TRPA1 activity as well as anti-nociceptive and anti-inflammatory activity in vivo.-

\section{MATERIAL AND METHODS}

\subsection{Chemistry}

All reagents and solvents were of the highest commercial quality available and used as received. Chalcones were synthesized as follows: an aqueous solution of sodium hydroxide $(30 \%, 25 \mathrm{~mL})$ was slowly added to a methanol solution $(30 \mathrm{~mL})$ of the appropriate acetophenone $(5.0 \mathrm{mmol})$. After the solution had been cooled to room temperature, the appropriate benzaldehyde $(6.0 \mathrm{mmol})$ was added. The mixture was stirred at room temperature overnight and was then poured into water $(100 \mathrm{~mL})$. The obtained solid was filtered, washed with water until reaching neutral $\mathrm{pH}$ and recrystallized from ethanol. The chemical structure was confirmed base on reported data (references [21-27] in Table 1).

\subsection{Cell Cultures}

HEK-293 (human embryonic kidney) and HEK-293 heterologously transfected with recombinant rat TRPA1 selected by G-418 (Geneticin; $600 \mu \mathrm{g} / \mathrm{ml}$ ), were grown as monolayers on $100 \mathrm{~mm}$ diameter Petri dishes in Minimum Essential Medium supplemented with non-essential amino acids, $10 \%$ fetal bovine serum and $2 \mathrm{mM}$ glutamine, and maintained under $5 \% \mathrm{CO}_{2}$ at $37^{\circ} \mathrm{C}$. HEK-293 cells were purchased from Deutsche Sammlung von Mikroorganismen und Zellkulturen GmbH (DSMZ, Braunschweig, Berlin, Germany). Cell culture medium and supplements were from Invitrogen.

\subsection{Assay of TRPA1-mediated Elevation of Intracellular} $\left[\mathrm{Ca}^{2+}\right]$

Compound effects on intracellular $\mathrm{Ca}^{2+}$ concentration $\left(\left[\mathrm{Ca}^{2+}\right]_{\mathrm{i}}\right)$ were determined using the selective intracellular fluorescent probe Fluo-4. On the day of the experiment, cells were loaded for $1 \mathrm{~h}$ at room temperature with Fluo-4-AM methyl ester ( $4 \mu \mathrm{M}$ in dimethyl sulfoxide containing $0.02 \%$ Pluronic F-127, Invitrogen) in Minimal Essential Medium without fetal bovine serum, then washed twice in a buffer containing $145 \mathrm{mM} \mathrm{NaCl}, 2.5 \mathrm{mM} \mathrm{KCl}, 1.5 \mathrm{mM} \mathrm{CaCl}_{2}, 1.2$ $\mathrm{mM} \mathrm{MgCl} 2,10 \mathrm{mM}$ D-glucose and $10 \mathrm{mM}$ HEPES, $\mathrm{pH} 7.4$, resuspended in the same buffer, and transferred (about 100,000 cells) to the quartz cuvette of the spectrofluorimeter (Perkin-Elmer LS50B equipped with PTP-1 Fluorescence Peltier System; PerkinElmer Life and Analytical Sciences, Waltham, MA, USA) under continuous stirring. The changes in $\left[\mathrm{Ca}^{2+}\right]_{\mathrm{i}}$ were determined before and after addition of various concentrations of test compounds by measuring cell fluorescence $\left(\lambda_{\mathrm{EX}}=488 \mathrm{~nm}, \lambda_{\mathrm{EM}}=516 \mathrm{~nm}\right)$ at $25^{\circ} \mathrm{C}$. Curve fitting (sigmoidal dose-response variable slope) and parameter estimation were performed with GraphPad Prism ${ }^{\circledR}$ (GraphPad Software Inc., San Diego, CA). Potency was expressed as the concentration of test compound exerting a half-maximal agonist effect (i.e., half-maximal increases in $\left.\left[\mathrm{Ca}^{2+}\right]_{\mathrm{i}}\right)\left(\mathrm{EC}_{50}\right)$. Agonist efficacy was expressed as a percentage of the effect on $\left[\mathrm{Ca}^{2+}\right]_{\mathrm{i}}$ observed with $100 \mu \mathrm{M}$ mustard oil (MO). When significant, values of the effect on $\left[\mathrm{Ca}^{2+}\right]_{\mathrm{i}}$ in wild-type (i.e., not transfected with any construct) HEK293 cells were taken as baseline and subtracted from the values obtained with transfected cells. Antagonist/ desensitising behavior was evaluated against $100 \mu \mathrm{M}$ MO by adding test compound to the quartz cuvette $5 \mathrm{~min}$ before agonist stimulation. Data are expressed as the concentration exerting half-maximal inhibition of agonist-induced $\left[\mathrm{Ca}^{2+}\right]_{\mathrm{i}}$ elevation $\left(\mathrm{IC}_{50}\right)$, which was calculated using GraphPad Prism $^{\circledR}$ software. The effect on $\left[\mathrm{Ca}^{2+}\right]_{i}$ exerted by MO alone was taken as $100 \%$. Dose-response curves were fitted by a sigmoidal regression with variable slope. All determinations were performed at least in triplicate. Statistical analysis was performed by analysis of variance at each point using ANOVA followed by Bonferroni's test.

\subsection{Animals}

Male C57BL/6J mice, 8 weeks old (Harlan, Italy), were housed 5 per cage under controlled illumination $(12: 12 \mathrm{~h}$ light: dark cycle; light on $06.00 \mathrm{~h})$ and standard environmental conditions (room temperature $22 \pm 1^{\circ} \mathrm{C}$, humidity $60 \pm 10 \%$ ) for at least one week before experimental use. Mouse chow and tap water were available ad libitum. Experimental procedures were in accordance with Italian and European regulations governing the care and treatment of laboratory animals (Permission no. 41/2007B). Animal care was in compliance with Ethical Guidelines of the IASP and European Community (E.C. L358/1 18/12/86) on the use and protection of animals in experimental research. All efforts were made to minimize animal suffering and to reduce the number of animals used. 
Table 1. Activity of Chalcones at rat TRPA1. Efficacy and Inhibition were Measured Versus $100 \mu$ M Mustard Oil (MO).<smiles></smiles>

\begin{tabular}{|c|c|c|c|c|c|c|}
\hline \multirow[t]{2}{*}{ Code } & \multirow[t]{2}{*}{$\mathbf{R}_{1}$} & \multirow[t]{2}{*}{$\mathbf{R}_{2}$} & \multirow[t]{2}{*}{ Ref. } & \multicolumn{3}{|c|}{ TRPA1 } \\
\hline & & & & $\begin{array}{c}\text { Efficacy } \\
(\% \text { MO 100 } \mu \mathrm{M})\end{array}$ & $\begin{array}{l}\text { Potency } \mu M \\
\quad\left(\text { EC }_{50}\right)\end{array}$ & $\begin{array}{l}\text { Inhibition } \mu \mathrm{M}\left(\mathrm{IC}_{50}\right) \\
\quad(\mathrm{vs} \mathrm{MO} 100 \mu \mathrm{M})\end{array}$ \\
\hline $\mathrm{C} 1$ & $3-\mathrm{NO}_{2}$ & 4-OMe & {$[21]$} & $107.7 \pm 1.7$ & $0.70 \pm 0.05$ & $0.49 \pm 0.01$ \\
\hline $\mathrm{C} 2$ & 4-Me & $\mathrm{H}$ & {$[22]$} & $80.2 \pm 3.3$ & $1.4 \pm 0.1$ & $1.7 \pm 0.1$ \\
\hline $\mathrm{C3}$ & $\mathrm{H}$ & 4-OMe & {$[23]$} & $74.2 \pm 2.9$ & $2.3 \pm 0.2$ & $3.3 \pm 0.2$ \\
\hline $\mathrm{C} 4$ & $3-\mathrm{NO}_{2}$ & $\mathrm{H}$ & {$[24]$} & $111.8 \pm 1.6$ & $0.27 \pm 0.02$ & $0.21 \pm 0.01$ \\
\hline $\mathrm{C} 5$ & $\mathrm{H}_{2}$ & 4-OMe & {$[25]$} & $88.2 \pm 1.4$ & $1.6 \pm 0.1$ & $2.2 \pm 0.1$ \\
\hline C6 & 4-OMe & $\mathrm{H}$ & {$[22]$} & $69.3 \pm 3.7$ & $1.9 \pm 0.2$ & $2.3 \pm 0.1$ \\
\hline C7 & 4-OMe & $3-\mathrm{NO}_{2}$ & {$[26]$} & $70.7 \pm 1.5$ & $0.94 \pm 0.05$ & $1.2 \pm 0.1$ \\
\hline $\mathrm{C8}$ & 4-OMe & 4-OMe & {$[23]$} & $83.2 \pm 5.7$ & $10.6 \pm 2.1$ & $8.7 \pm 1.1$ \\
\hline C9 & $\mathrm{H}$ & $\mathrm{H}$ & {$[23]$} & $108.1 \pm 3.3$ & $2.6 \pm 0.3$ & $2.1 \pm 0.1$ \\
\hline C10 & $4-\mathrm{Cl}$ & 4-OMe & {$[27]$} & $92.5 \pm 3.0$ & $1.0 \pm 0.1$ & $0.82 \pm 0.05$ \\
\hline C11 & $4-\mathrm{Cl}$ & $\mathrm{H}$ & {$[22]$} & $118.9 \pm 4.2$ & $1.4 \pm 0.2$ & $0.71 \pm 0.04$ \\
\hline
\end{tabular}

\subsection{Eye-Wiping Test}

The pain-inducing potency of $\mathrm{C} 1, \mathrm{C} 4, \mathrm{C} 10$ and $\mathrm{C} 11$ was determined by the eye-wiping assay in mice, a sensitive animal model for acute trigeminal pain studies, using a protocol similar to that described in rats [28]. Male $\mathrm{C} 57 \mathrm{BL} / 6 \mathrm{~J}$ mice were maintained in a controlled lighting environment and groups of 6-8 animals were used for each treatment. The animals received drug instillations $(10 \mu \mathrm{l})$ in the left eye and were used for one treatment only. The number of eye-wiping movements following drug instillation into the eye was considered as an index of pungency. The eye-wiping reflexes in response to $\mathrm{MO}(10 \mu \mathrm{g} / \mathrm{ml})$, or $\mathrm{C} 1$, $\mathrm{C} 4, \mathrm{C} 10, \mathrm{C} 11$ dropped in solution into the eye, was determined $10 \mathrm{~min}$ after the instillation.

In another set of experiments the effects of topical $\mathrm{C} 4$ and $\mathrm{C} 1$ on MO-induced eye-wiping were studied. Mice were treated as follows:
(A) $\mathrm{MO}(10 \mu \mathrm{g} / \mathrm{ml})$
(B) $\mathrm{C} 1(10 \mu \mathrm{g} / \mathrm{ml}, 30$ or $120 \mathrm{~min})+\mathrm{MO}(10 \mu \mathrm{g} / \mathrm{ml})$
(C) $\mathrm{C} 4(10 \mu \mathrm{g} / \mathrm{ml}, 30$ or $120 \mathrm{~min})+\mathrm{MO}(10 \mu \mathrm{g} / \mathrm{ml})$

\subsection{Formalin Test}

Formalin injection induces a biphasic stereotypical nocifensive behavior [29]. Nociceptive responses are divided into an early, short-lasting first phase $(0-7 \mathrm{~min})$ caused by a primary afferent discharge produced by the stimulus, followed by a quiescent period and then a second, prolonged phase (15-60 $\mathrm{min}$ ) of tonic pain. Mice received formalin $(1.25 \%$ in saline, $30 \mu \mathrm{l})$ in the dorsal surface of one side of the hindpaw. Each mouse was randomly assigned to one of the experimental groups and placed in a plexiglas cage and allowed to move freely for $30 \mathrm{~min}$. A mirror was placed at a 45-degree angle under the cage to allow full view of the hindpaws. Lifting, favoring, licking, shaking, and flinching of the injected paw were recorded as nociceptive responses. The duration of these noxious behaviors was monitored by an observer blind to the experimental treatment for periods of 0-10 min (early phase) and 20-60 min (late phase) after formalin administration. Groups of 6-8 animals per treatment were used with each animal being used for one treatment only. Mice received vehicle (5\% dimethylsulfoxide in $0.9 \%$ $\mathrm{NaCl})$ or different doses of $\mathrm{C} 1, \mathrm{C} 4, \mathrm{C} 10$ or $\mathrm{C} 11(0.75,1.5$ and $3 \mu \mathrm{g} / \mathrm{paw}, 30 \mu \mathrm{l}$ ) administered $10 \mathrm{~min}$ before formalin or saline.

\section{RESULTS}

\subsection{Effect of Chalcones on MO-Induced rat TRPA1- Mediated Elevation of $\left[\mathrm{Ca}^{2+}\right]_{i}$}

We evaluated the possible inhibitory effect of chalcones on TRPA1-mediated $\left[\mathrm{Ca}^{2+}\right]_{\mathrm{i}}$ elevation induced by $100 \mu \mathrm{M}$ MO. Compounds were added $5 \mathrm{~min}$ before cell exposure to MO (Fig. 1). The observed inhibitory effect is likely due to desenitisation rather than antagonism, since: 1) chalcones per se added to cells produced a concentration-dependent increase in $\left[\mathrm{Ca}^{2+}\right]_{\mathrm{i}}$ at concentrations similar to those necessary to inhibit the MO effect (Fig. 2), and 2) MO also inhibited its own effect when administered to cells in two consecutive times $\left(\mathrm{IC}_{50} 1.71 \pm 0.06 \mu \mathrm{M}\right)$ [30]. The values of efficacy (expressed as \% of MO) and potency $\left(\mathrm{EC}_{50}\right)$ as well as the inhibition of increase in $\left[\mathrm{Ca}^{2+}\right]_{\mathrm{i}}$ elevation induced by MO $\left(\mathrm{IC}_{50}\right)$ are listed in Table 1 . The four compounds with 
$\mathrm{IC}_{50}$ below $1 \mu \mathrm{M}$ were selected for testing in the eye-wiping and formalin assays in mice.

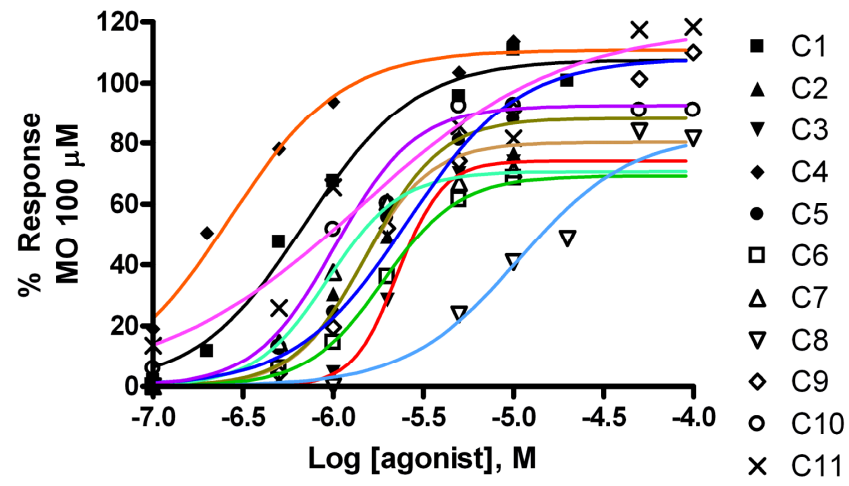

Fig. (1). Dose-response effects of chalcones on the effect on intracellular $\mathrm{Ca}^{2+}$ in HEK-293-TRPA1 cells by $100 \mu \mathrm{M}$ mustard oil (MO). Data are means \pm SEM of $n=4$ different determinations.

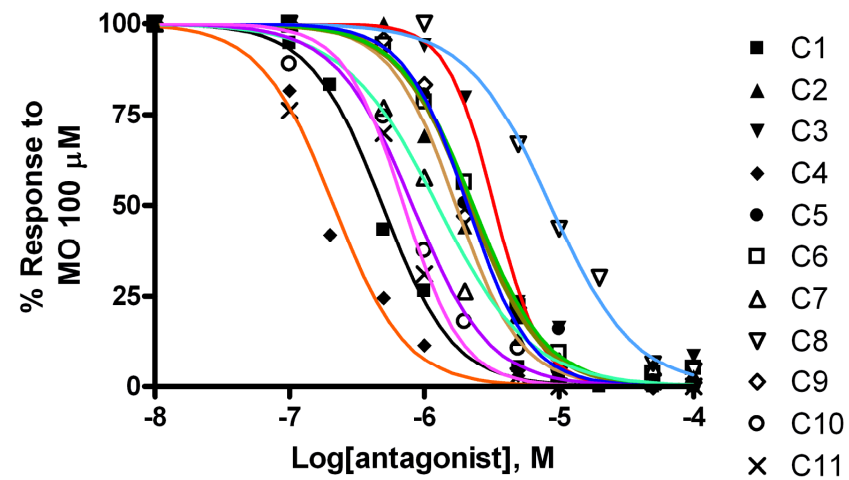

Fig. (2). Dose-dependent effects of chalcones on elevation of intracellular calcium in HEK-293 cells overexpressing rat TRPA1. Data are means \pm SEM of $\mathrm{n}=4$ different determinations. The compounds were tested also on HEK-293 cells not transfected with TRPA1: none produced a significant elevation of intracellular $\mathrm{Ca}^{2+}$.

\subsection{Effect of Topical MO and $\mathrm{C} 1, \mathrm{C} 4, \mathrm{C} 10$ and $\mathrm{C} 11$ on Eye-Wiping in Mice}

The eye-wiping test was employed as an in vivo pungency test to assess the pain-producing effects of topical drugs. The instillation of $10 \mu \mathrm{l}$ of allyl isothiocyanate solution (MO, $10 \mu \mathrm{g} / \mathrm{ml}$ ), used as comparator drug, evoked $28.9 \pm 2.3$ wiping movements monitored within $10 \mathrm{~min}$. Moreover, we observed different pungency profiles for the various compounds tested. In particular, C10 proved to be the most pungent. No significant changes were seen following C10 topical application (10 and $30 \mu \mathrm{g} / \mathrm{ml}$ ) as compared with MO. However, compounds $\mathrm{C} 1, \mathrm{C} 4$ and $\mathrm{C} 11$ showed significantly lower pungent properties. In particular, the wiping movements were $8.7 \pm 2.2$ and $6.8 \pm 2.9$ for $\mathrm{C} 1$ (10 and $30 \mu \mathrm{g} / \mathrm{ml}$, respectively); $8.7 \pm 2.3$ and $5.8 \pm 2.0$ for C4 (10 and $30 \mu \mathrm{g} / \mathrm{ml}$, respectively); and $25.2 \pm 5.6$ and $6 \pm$ 2.7 for C11 (10 and $30 \mu \mathrm{g} / \mathrm{ml}$, respectively) (Fig. 3).

\subsection{Effect of Topical $\mathrm{C} 4$ and $\mathrm{C} 1$ on MO-Induced Eye- Wiping in Mice}

The two compounds with lowest eye-wiping activity, $\mathrm{C} 1$ and $\mathrm{C} 4$, were also tested on $\mathrm{MO}(10 \mu \mathrm{g} / \mathrm{ml})$ (Fig. 4) induction of such activity, given their TRPA1 desensitising activity in transfected HEK-293 cells. C4 pre-treatment (30 and $120 \mathrm{~min})$ significantly reduced $(12.5 \pm 3.2$ and $11.6 \pm$ 4.0 , respectively) the number of eye-wiping movements induced by application of MO $(41.5 \pm 2.8)$. Interestingly $\mathrm{C} 1$, applied $30 \mathrm{~min}$ before $\mathrm{MO}$ in the same eye, increased pain behavior (68.6 \pm 11.0$)$, although this was significantly decreased $(10 \pm 0.89)$ at $120 \mathrm{~min}$ in pre-treated mice, as compared to $\mathrm{MO}$ alone $(33.2 \pm 2.0)$.

\subsection{C1, C4, C10 and C11 Inhibit Formalin-Induced Nocifensive Behavior in Mice}

The activity of compounds $\mathrm{C} 1, \mathrm{C} 4, \mathrm{C} 10$ and $\mathrm{C} 11$ was evaluated in the formalin test of acute peripheral and inflammatory pain in mice. Formalin-treated mice showed the typical nociceptive behavior characterized by an early, short-lasting first phase (0-7 min), followed by a quiescent period, and then a second, prolonged phase (15-60 $\mathrm{min}$ ) of tonic pain [29]. Ten minutes before injection of formalin $(1.25 \%, 30 \mu 1)$, mice received intrapaw administration of vehicle or one of the four compounds $(0.75,1.5$ and $3 \mu \mathrm{g} /$ $30 \mu 1)$. In spite of their diverse efficacies, all drugs exhibited antinociceptive activity in formalin-treated animals. In fact, we observed a significant dose-dependent reduction of both the first and the second phase of nocifensive response, as compared with vehicle-treated mice. Interestingly, C4mediated analgesic effects exhibited an inverted doseactivity relationship, being most active at the lowest dose tested $(0.75 \mu \mathrm{g} / \mathrm{paw})$, but ineffective at the highest dose (Fig. 5).

\section{DISCUSSION}

TRPA1 [31] is a polymodal nociceptor that detects noxious chemical agents, whether exogenous or produced endogenously during tissue injury, inflammation and oxidative stress $[32,33]$. The structure of TRPA1 suggests that it functions as a sensitive, low-threshold electrophile receptor [34]. The contribution of TRPA1 to the initial phase of the inflammatory process and its participation in chronic inflammatory pain has been explored $[35,36]$. Antagonists of this ion channel have the potential for treating neurogenic inflammatory conditions. TRPA1 is up-regulated following inflammatory injury [37], whereas in nerve endings TRPA1 is activated by inflammatory mediators contributing to hyperalgesia [38]. Further, TRPA1 is a key molecular target in both neuropathic pain [39] and diabetic neuropathy [40, 41]. In the current study, we demonstrate a potential novel mechanism of action for 11 compounds belonging to the chalcone family, i.e. their ability to mediate elevation of $\left[\mathrm{Ca}^{2+}\right]_{\mathrm{i}}$ in HEK293-TRPA1 cells and subsequently desensitise TRPA1 in a heterologous expression system.

Four of the tested chalcone derivatives, C4, C1, C7 and $\mathrm{C} 10$ were more potent than mustard oil. At least four of the 
EYE WIPING
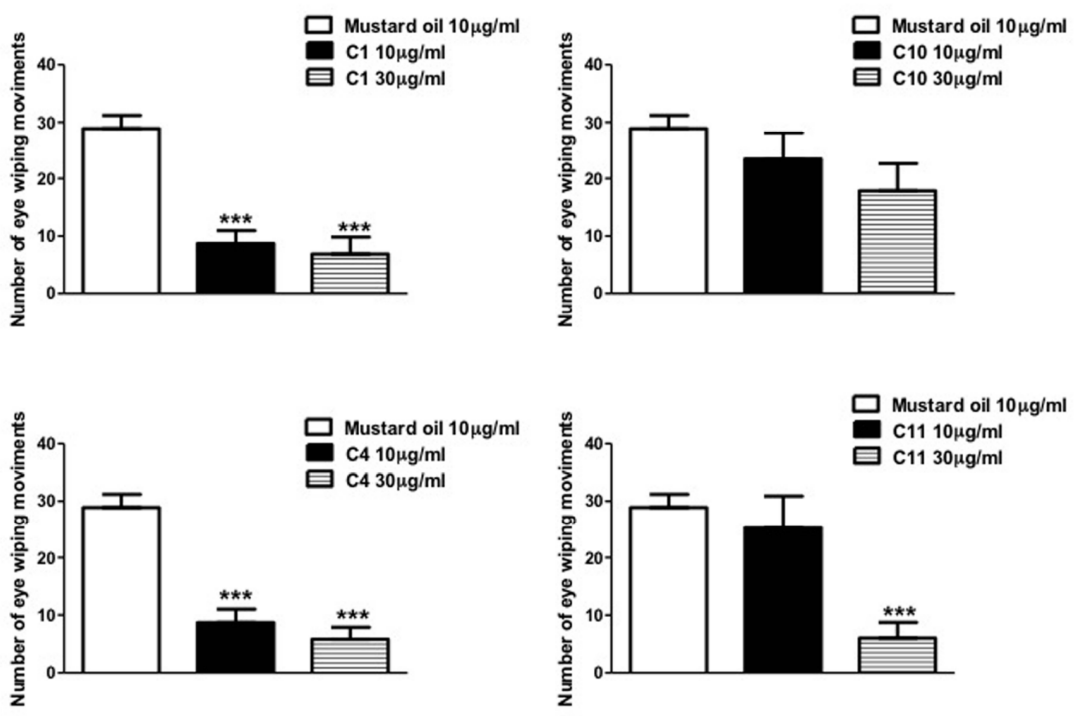

Fig. (3). Effect of $\mathrm{C} 1, \mathrm{C} 4, \mathrm{C} 10$ and $\mathrm{C} 11(10$ and $30 \mu \mathrm{g} / \mathrm{ml})$ topical administration $(10 \mu \mathrm{l})$ on the number of wiping movements into the left eye. Data are means \pm SEM of $n=6-8$ mice per group. Statistical significance was determined by one-way ANOVA, followed by Tukey's post-hoc test. $* * * \mathrm{P}<0.001$ vs mustard oil-treated animals.

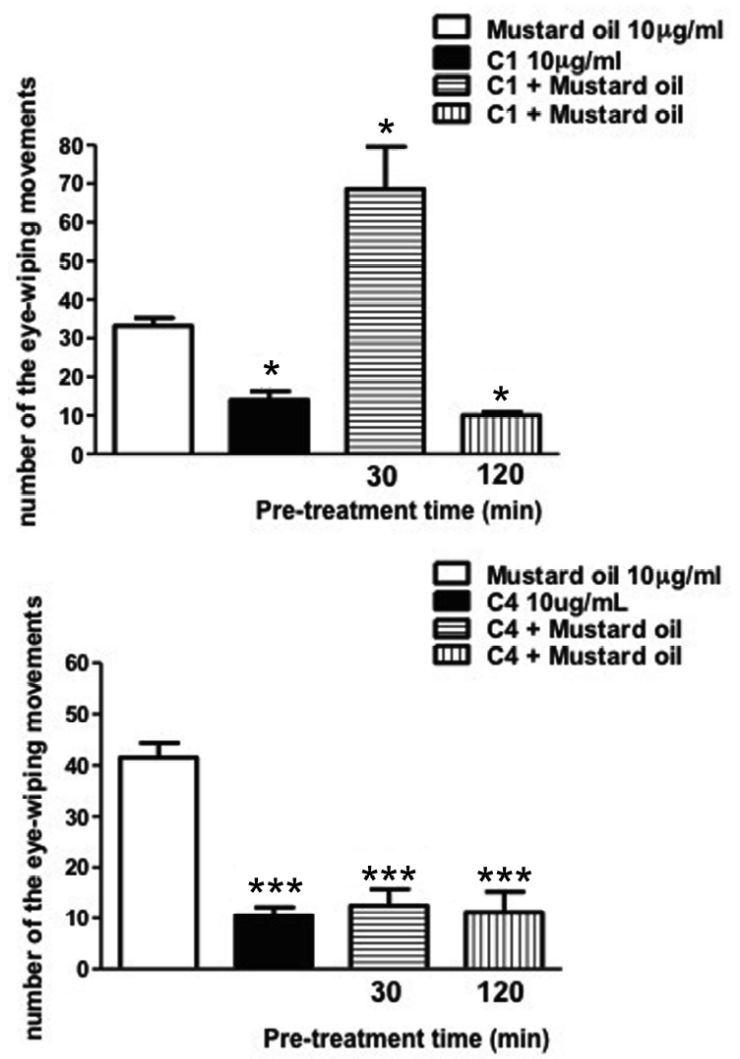

Fig. (4). Effect of $\mathrm{C} 1$ or $\mathrm{C} 4(10 \mu \mathrm{g} / \mathrm{ml})$ topical administration $(10 \mu \mathrm{l})$ on the number of wiping movements induced by Mustard oil $(\mathrm{MO}, 10 \mu \mathrm{g} / \mathrm{ml})$ into the left eye. $\mathrm{C} 1$ or $\mathrm{C} 4$ were applied 30 or 120 min before mustard oil. Data are means \pm SEM of $n=6-8$ mice per group. Statistical significance was determined by One-way ANOVA followed by Tukey's post-hoc test. $* \mathrm{P}<0.05$ and $* * * \mathrm{P}<0.001$ vs MO-treated animals. tested chalcones were significantly more potent at desensitising mustard oil than mustard oil itself. Unlike mustard oil, some chalcones were not pungent in the eyewiping assay, possibly due to their lipophilic nature. Indeed, several TRPV1 agonists which exhibit a slower onset of activation and high lipophilicity are also non-pungent [4952]. Although non-pungent per se, some chalcones inhibit in a long-lasting and dose-dependent manner the mustard oilinduced response in the formalin test, likely due to TRPA 1 desensitisation to the action of mustard oil. The formalin test shows a biphasic pain-related behavior, with the first phase been attributed to TRPA1-mediated excitation of nociceptors, and the second phase to their inflammatory and/or spinal sensitisation. [53]. Either pharmacological blockade or genetic deletion of TRPA1 markedly reduces both the first and second phases of the nociceptive response induced by formalin in the rat and mouse paw [20]. The TRPA1 antagonist HC-030031 inhibits the first phase of the formalin response, confirming a role for TRPA1 in this response [20].

At first glance these findings may appear difficult to rationalise given that chalcones activate TRPA1, a target of numerous hazardous/reactive chemicals such the pronociceptive and pro-inflammatory agent mustard oil. The structurally similar compound, curcumin, a bis- $\alpha, \beta$ unsaturated $\beta$-diketone of two ferulic acid units connected through a methylene group, is a typical Michael acceptor [42]. Curcumin selectively activates and subsequently desensitises human [43] and rat TRPA1 in heterologous expression systems [44]. Curcumin has antioxidant, antiinflammatory, anticancer, antiviral, antibacterial, antidiabetic, anti-proliferative and pro-apoptotic properties, and clinical trials are underway to identify its potential beneficial effects [45]. Most of the these activities have been linked to curcumin's $\alpha, \beta$-unsaturated carbonyl moiety [46]. Curcumin inhibits the proliferation and survival of almost all types of 


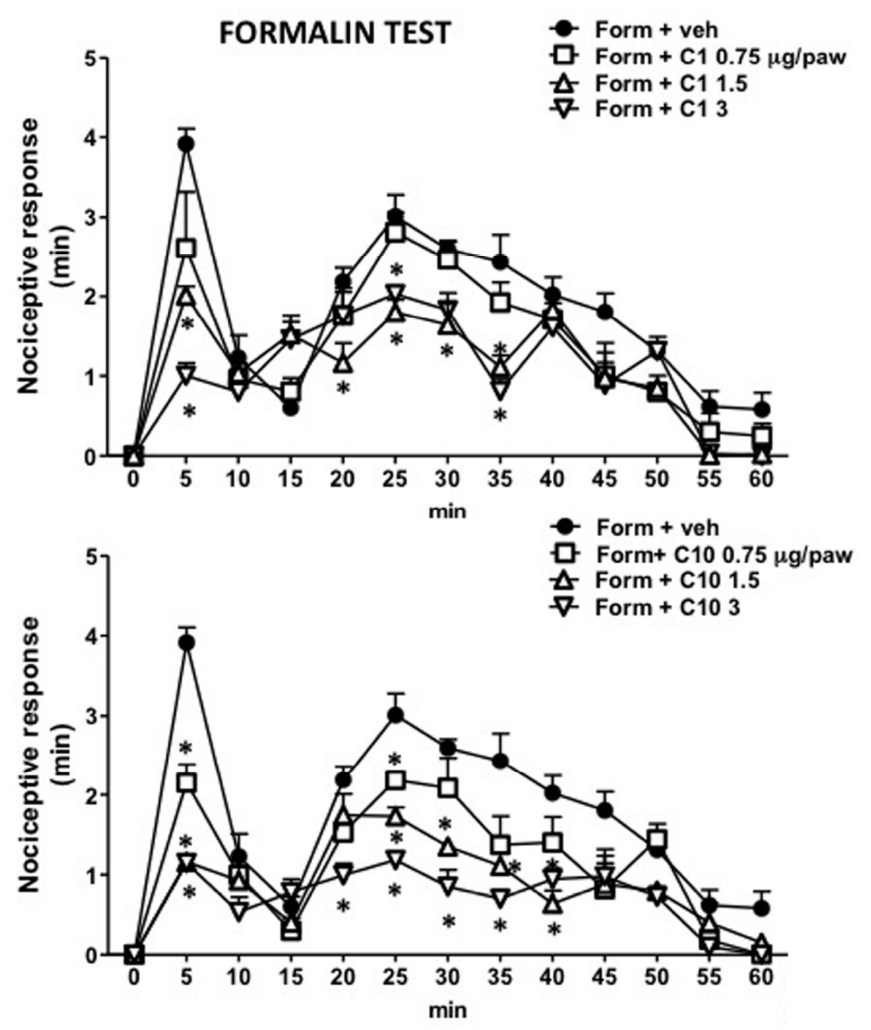

(a)
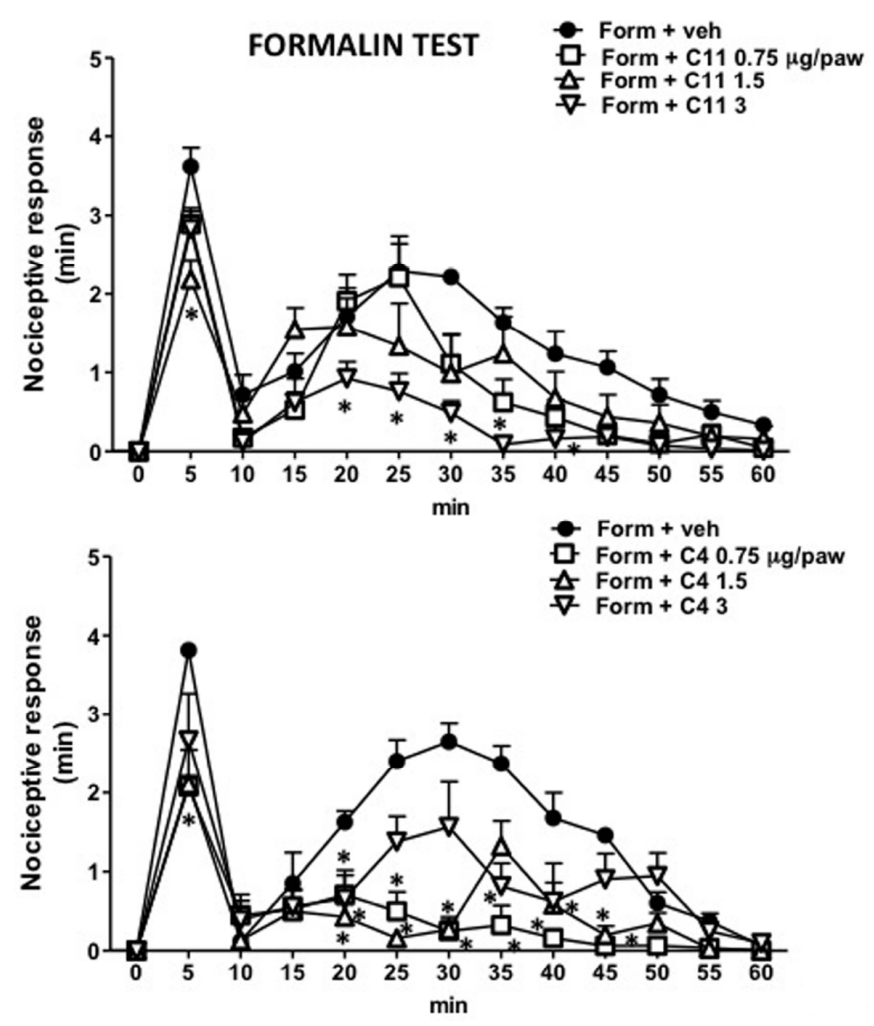

(b)

Fig. (5). Effect of $\mathrm{C} 1, \mathrm{C} 4, \mathrm{C} 10$ and $\mathrm{C} 11(0.75,1.5$ and $3 \mu \mathrm{g} / \mathrm{paw})$ in the formalin test in mice. The total time of the nociceptive response was measured every $5 \mathrm{~min}$ and expressed in minutes. Statistical significance was determined by two-way analysis of variance followed by Turkey-Kramer post-hoc test. ${ }^{*} \mathrm{P}<0.05$ vs formalin+ vehicle-treated animals.

tumour cells so far examined [47]. Its anti-inflammatory effects are mediated by suppression of the transcription factor NF-kB, which is activated in response to various carcinogens, growth factors and inflammatory cytokines [48]. It is worth noting that curcumin caused a strong desensitization and tachyphylaxis in a recombinant TRPA1 system and may activate the channel efficaciously without producing noxious sensations.

These findings strongly suggest that chalcones can be considered as novel candidates for the development of antihyperalgesic preparations based on TRPA1 desensitization. Indeed, the combination of significantly higher potency as a TRPA1-desensitizing agent and lower pungency should make these compounds useful tools for the treatment of neuropathic pain. In will be important in future studies to establish if chalcones are capable of producing antihyperalgesic actions in animal models of chronic inflammatory and neuropathic pain. The present study already shows that intraplantar injection of some chalcones in mice not only fails to cause nociception but also inhibits the second phase of the nocifensive response to formalin, a widely used model of acute inflammatory pain.

Interestingly, the four most potent compounds at desensitising TRPA1 are chalcones with a substituent electron-acceptor in the B ring which is closer to the $\alpha, \beta$ unsaturated carbon, and whose nitro group is more efficient than a chlorine. The presence of a methoxy group in the other ring renders the compounds less active. This is in agreement with the hypothesis that the $\alpha$ - $\beta$-unsaturated ketone system in the structure of chalcones activates and desensitize TRPA1 via the formation of a covalent Michael adduct with cysteine residues within the channel $[18,19]$. The $\mathrm{IC}_{50}$ rank is:

$$
\mathrm{C} 4<\mathrm{C} 1<\mathrm{C} 11<\mathrm{C} 10
$$

Although the presence of an electron-acceptor nitro group on the other ring does not appear to markedly impact TRPA1 agonist activity $\left(\mathrm{EC}_{50} \mathbf{C 1}=0.70 \pm 0,05 \mathrm{EC}_{50} \mathbf{C 7}=\right.$ $0.94 \pm 0.05)$, it approximately doubles the $\mathrm{IC}_{50}\left(\mathrm{IC}_{50} \mathbf{C 1}=\right.$ $\left.0.49 \pm 0.01 \mathrm{IC}_{50} \mathbf{C 7}=1.2 \pm 0.1\right)$. It is intriguing to note that a series of chalcone derivatives tested for their antiproliferative activities against a panel of cancer cells showed, in general, that compounds containing nitro groups on the ring near the $\alpha-\beta$-unsaturation were more potent and selective [54].

The importance of a nitro substituent in the ring for chalcone biological activity has been shown in vivo and in vitro. Chalcone derivatives with an electron-acceptor nitro group substituent in the $\mathrm{A}$ and $\mathrm{B}$ rings have antihyperglycemic activity, increasing insulin secretion together with serum glucose-lowering in the presence of functional $\beta$ cells. Only chalcones with a nitro group at position 3 on ring $\mathrm{B}$, the same position as our $\mathrm{C} 4$, showed significant and acute anti-hyperglycemic activity in short-term treatment, in contrast to when the electron-acceptor nitro group is at position 2' in ring A [55]. Indeed, TRPA1 is abundantly 
expressed in a rat pancreatic $\beta$ cell line, and its activation by endogenous and exogenous ligands stimulates insulin release [56]. Chalcones are being considered for the management not only of diabetes but also treatment of several pathologies $[3,57]$. A series of chalcone derivatives (curcumin analogs) showed anti-inflammatory activity in mouse RAW 264.7 macrophages, inhibiting the lipopolysaccharide-induced expression of tumour necrosis- $\alpha$ and interleukin-6 [58]. Structure-activity studies show that the asymmetric compounds possessed higher anti-inflammatory activity, while electronegativity was an important factor for inhibiting lipopolysaccharide-induced interleukin-6 expression. Some nitro-substituted chalcones have also been proposed for the treatment of neurodegenerative diseases such as parkinsonian syndromes [59].

\section{CONCLUSION}

Eleven compounds, belonging to the chalcone family, were able to desensitise TRPA1. Several were not pungent in the eye-wiping assay and quite remarkably inhibited, in a long-lasting and dose-dependent manner the mustard oilinduced response in the formalin test. Chalcones can be considered as novel candidates for the development of antihyperalgesic preparations based on TRPA1 desensitization.

\section{LIST OF ABBREVIATIONS}

\begin{tabular}{|c|c|c|}
\hline MO & $=$ & Allyl isothiocyanate (mustard oil,); \\
\hline $\mathrm{NF}-\kappa \mathrm{B}$ & $=$ & Nuclear factor- $\kappa \mathrm{B}$; \\
\hline TRPA1 & $=$ & $\begin{array}{l}\text { Transient receptor potential ankyrin } \\
\text { cation channel, subfamily A, member } 1 .\end{array}$ \\
\hline
\end{tabular}

\section{CONFLICT OF INTEREST}

The authors confirm that this article content has no conflict of interest.

\section{ACKNOWLEDGEMENTS}

Declared none.

\section{REFERENCES}

[1] Di Carlo G, Mascolo N, Izzo AA, Capasso F. Flavonoids: old and new aspects of a class of natural therapeutic drugs. Life Sci 1999; 65: 337-53.

[2] Dimmock JR, Elias DW, Beazely MA, Kandepu NM. Bioactivities of chalcones. Curr Med Chem 1999; 6: 1125-49.

[3] Matos MJ, Vazquez-Rodriguez S, Uriarte E, Santana L. Potential pharmacological uses of chalcones: a patent review (from June 2011 - 2014). Expert Opin Ther Pat 2015; 25: 351-66.

[4] Singh P, Anand A, Kumar V. Recent developments in biological activities of chalcones: a mini review. Eur J Med Chem 2014; 85: 758-77.

[5] Mahapatra DK, Bharti SK, Asati V. Anti-cancer chalcones: Structural and molecular target perspectives. Eur J Med Chem 2015; 98: 69-114.

[6] Brunhofer-Bolzer G, Le T, Dyckmanns N, et al. SAR-guided development and characterization of a potent antitumor compound toward B-cell neoplasms with no detectable cytotoxicity toward healthy cells. J Med Chem 2015; 58: 1244-53.

[7] Murthy YL, Suhasini KP, Pathania AS, Bhushan S, Nagendra Sastry Y. Synthesis, structure activity relationship and mode of action of 3-substitutedphenyl-1-(2,2,8,8-tetramethyl-3,4,9,10tetrahydro-2H,8H-pyrano[2,3-f]chromen-6-yl)-propenones as novel anticancer agents in human leukaemia HL-60 cells. Eur J Med Chem 2013; 62: 545-55.

[8] Karpaviciene I, Cikotiene I, Padrón JM. Synthesis and antiproliferative activity of $\alpha$-branched $\alpha, \beta$-unsaturated ketones. Eur J Med Chem 2013; 70: 568-78.

[9] Pedrini FS, Chiaradia LD, Licínio MA, et al. Induction of apoptosis and cell cycle arrest in L-1210 murine lymphoblastic leukaemia cells by (2E)-3-(2-naphthyl)-1-(3'-methoxy-4'-hydroxy-phenyl)-2propen-1-one. J Pharm Pharmacol 2010; 62: 1128-36.

[10] Ismail B, Ghezali L, Gueye R, et al. Novel methylsulfonyl chalcones as potential antiproliferative drugs for human prostate cancer: involvement of the intrinsic pathway of apoptosis. Int $\mathbf{J}$ Oncol 2013; 43: 1160-8.

[11] Singh N, Sarkar J, Sashidhara KV, Ali S, Sinha S. Anti-tumour activity of a novel coumarin-chalcone hybrid is mediated through intrinsic apoptotic pathway by inducing PUMA and altering Bax/Bcl-2 ratio. Apoptosis 2014; 19: 1017-28.

[12] Qi Z, Liu M, Liu Y, Zhang M, Yang G. Tetramethoxychalcone, a chalcone derivative, suppresses proliferation, blocks cell cycle progression, and induces apoptosis of human ovarian cancer cells. PLoS One 2014; 9: e106206.

[13] Jung SK, Lee MH, Lim do Y, et al. Isoliquiritigenin induces apoptosis and inhibits xenograft tumor growth of human lung cancer cells by targeting both wild type and L858R/T790M mutant EGFR. J Biol Chem 2014; 289: 35839-48.

[14] Zhong P, Wu L, Qian Y, et al. Blockage of ROS and NF-кBmediated inflammation by a new chalcone L6H9 protects cardiomyocytes from hyperglycemia-induced injuries. Biochim Biophys Acta 2015; 1852: 1230-41.

[15] Bukhari SN, Jantan I, Jasamai M. Anti-inflammatory trends of 1,3diphenyl-2-propen-1-one derivatives. Mini Rev Med Chem 2013; 13: 87-94.

[16] Sahu NK, Balbhadra SS, Choudhary J, Kohli DV. Exploring pharmacological significance of chalcone scaffold: a review. Curr Med Chem 2012; 19: 209-25.

[17] Amslinger S. The tunable functionality of $\alpha, \beta$-unsaturated carbonyl compounds enables their differential application in biological systems. ChemMedChem 2010; 5(3): 351-6.

[18] Hinman A, Chuang HH, Bautista DM, Julius D. TRP channel activation by reversible covalent modification. Proc Natl Acad Sci USA 2006; 103: 19564-8.

[19] Macpherson LJ, Dubin AE, Evans MJ, et al. Noxious compounds activate TRPA1 through covalent modification of cysteines. Nature 2007; 445: 541-5.

[20] McNamara CR, Mandel-Brehm J, Bautista DM, et al. TRPA1 mediates formalin-induced pain. Proc Natl Acad Sci USA 2007; 104: $13525-30$.

[21] Supuran CT, Popescu A, Ilisiu M, Costandache A, Banciu MD Carbonic anhydrase inhibitors. Part 36. Inhibition of isozymes I and II with Schiff bases derived from chalkones and aromatic/heterocyclic sulphonamides. Eur J Med Chem 1996; 31: 439-47.

[22] Kubota Y, Ikeya H, Sugi Y, Yamada T, Tatsumi T. Organicinorganic hybrid catalysts based on ordered porous structures for Michael reaction. J Mol Catalysis A Chem 2006; 249: 181-90.

[23] Schmink JR, Holcomb JL, Leadbeater NE. Testing the validity of microwave-interfaced, in situ Raman spectroscopy as a tool for kinetic studies. Org Lett 2009; 11: 365-8.

[24] Huang X, Xie L, Wu LH. Synthetic applications of organotellurium compounds. 1. A facile synthesis of $\alpha, \beta$-unsaturated esters, ketones, and nitriles. J Org Chem 1988; 53: 4862-4.

[25] Ducki S, Rennison D, Woo M, et al. Combretastatin-like chalcones as inhibitors of microtubule polymerization. Part 1: synthesis and biological evaluation of antivascular activity. Bioorg Med Chem 2009; 17: 7698-710.

[26] Balaji PN, Sreevani MS, Harini P, Johnsi RP, Prathusha K, Chandu TJ. Antimicrobial activity of some novel synthesized heterocyclic compounds from substituted chalcones. J Chem Pharm Res 2010; 2: 754-8.

[27] Kumar R, Mohanakrishnan D, Sharma A, et al. Reinvestigation of structure-activity relationship of methoxylated chalcones as antimalarials: synthesis and evaluation of 2,4,5-trimethoxy substituted patterns as lead candidates derived from abundantly available natural $\beta$-asarone. Eur J Med Chem 2010; 45: 5292-301. 
[28] Szallasi A, Blumberg PM. Resiniferatoxin, a phorbol-related diterpene, acts as an ultrapotent analog of capsaicin, the irritant constituent in red pepper. Neuroscience 1989; 30: 515-20.

[29] Abbott FV, Guy ER. Effects of morphine, pentobarbital and amphetamine on formalin- induced behaviors in infant rats: sedation versus specific suppression of pain. Pain 1995; 62: 30312.

[30] Del Prete D, Caprioglio D, Appendino G, et al. Discovery of nonelectrophilic capsaicinoid-type TRPA1 ligands. Bioorg Med Chem Lett 2015, 25: 1009-11.

[31] Story GM, Peier AM, Reeve AJ, et al. ANKTM1, a TRP-like channel expressed in nociceptive neurons, is activated by cold temperatures. Cell 2003; 112: 819-29.

[32] Bautista DM, Pellegrino M, Tsunozaki M. TRPA1: A gatekeeper for inflammation. Annu Rev Physiol 2013; 75: 181-200.

[33] Nilius B, Appendino G, Owsianik G. The transient receptor potential channel TRPA1: from gene to pathophysiology. Pflugers Arch 2012; 464: 425-58.

[34] Paulsen CE, Armache JP, Gao Y, Cheng Y, Julius D. Structure of the TRPA1 ion channel suggests regulatory mechanisms. Nature 2015; 520: 511-7.

[35] Petrus M, Peier AM, Bandell M, et al. A role of TRPA1 in mechanical hyperalgesia is revealed by pharmacological inhibition. Mol Pain 2007; 3: 40-59.

[36] Eid SR, Crown ED, Moore EL, et al. HC-030031, a TRPA1 selective antagonist, attenuates inflammatory- and neuropathyinduced mechanical hypersensitivity. Mol Pain 2008; 4: 48.

[37] da Costa DS, Meotti FC, Andrade EL, Leal PC, Motta EM, Calixto JB. The involvement of the transient receptor potential A1 (TRPA1) in the maintenance of mechanical and cold hyperalgesia in persistent inflammation. Pain 2010; 148: 431-7.

[38] Patapoutian A, Tate S, Woolf CJ. Transient receptor potential channels: targeting pain at the source. Nature Rev Drug Discov 2009; 8: 55-68.

[39] Obata K, Katsura H, Mizushima T, et al. TRPA1 induced in sensory neurons contributes to cold hyperalgesia after inflammation and nerve injury. J Clin Invest 2005; 115: 2393-401.

[40] Wei H, Chapman H, Saarnilehto M, Kuokkanen K, Koivisto A, Pertovaara A. Roles of cutaneous versus spinal TRPA1 channels in mechanical hypersensitivity in the diabetic or mustard oil-treated non-diabetic rat. Neuropharmacology 2010; 58: 578-84.

[41] Eberhardt MJ, Filipovic MR, Leffler A, et al. Methylglyoxal activates nociceptors through Transient Receptor Potential Channel A1 (TRPA1): a possible mechanism of metabolic neuropathies. J Biol Chem 2012; 287: 28291-306.

[42] Esatbeyoglu T, Huebbe P, Ernst IM, Chin D, Wagner AE, Rimbach G. Curcumin--from molecule to biological function. Angew Chem Int Ed Engl 2012; 51: 5308-32.

[43] Leamy AW, Shukla P, McAlexander MA, Carr MJ, Ghatta S. Curcumin ((E,E)-1,7-bis(4-hydroxy-3-methoxyphenyl)-1,6heptadiene-3,5-dione) activates and desensitizes the nociceptor ion channel TRPA1. Neurosci Lett 2011; 503: 157-62.
[44] Avonto C, Taglialatela-Scafati O, Pollastro F, et al. An NMR spectroscopic method to identify and classify thiol-trapping agents: revival of Michael acceptors for drug discovery? Angew Chem Int Ed Engl 2011; 50: 467-71.

[45] https://clinicaltrials.gov/ct2/results?term=curcumin PROVIDE COMPLETE REFERENCE

[46] Aggarwal BB, Deb L, Prasad S. Curcumin differs from tetrahydrocurcumin for molecular targets, signaling pathways and cellular responses. Molecules 2014; 20: 185-205.

[47] Aggarwal BB, Sung B. Pharmacological basis for the role of curcumin in chronic diseases: an age-old spice with modern targets. Trends Pharmacol Sci 2009; 30: 85-94.

[48] Bhattacharyya S, Mandal D, Saha B, Sen GS, Das T, Sa G. Curcumin prevents tumor-induced T cell apoptosis through Stat-5amediated Bcl-2 induction. J Biol Chem 2007; 282: 15954-64.

[49] Morita A, Iwasaki Y, Kobata K, et al. Lipophilicity of capsaicinoids and capsinoids influences the multiple activation process of rat TRPV1. Life Sci 2006; 79: 2303-10.

[50] Lazar J, Braun DC, Tóth A, et al. Kinetics of penetration influence the apparent potency of vanilloids on TRPV1. Mol Pharmacol 2006; 69: 1166-73.

[51] Ursu D, Knopp K, Beattie RE, Liu B, Sher E. Pungency of TRPV1 agonists is directly correlated with kinetics of receptor activation and lipophilicity. Eur J Pharmacol 2010; 641: 114-22.

[52] De Petrocellis L, Guida F, Schiano Moriello A, et al. N-palmitoylvanillamide (palvanil) is a non-pungent analog of capsaicin with stronger desensitizing capability against the TRPV1 receptor and anti-hyperalgesic activity. Pharmacol Res 2011; 63: 294-9.

[53] Fischer M, Carli G, Raboisson P, Reeh P. The interphase of the formalin test. Pain 2014; 155: 511-21

[54] Mai CW, Yaeghoobi M, Abd-Rahman N, Kang YB, Pichika MR. Chalcones with electron-withdrawing and electron-donating substituents: anticancer activity against TRAIL resistant cancer cells, structure-activity relationship analysis and regulation of apoptotic proteins. Eur J Med Chem 2014; 77: 378-87.

[55] Damazio RG, Zanatta AP, Cazarolli LH, et al. Nitrochalcones: potential in vivo insulin secretagogues. Biochimie 2009; 91: 14938.

[56] Cao DS, Zhong L, Hsieh TH, et al. Expression of transient receptor potential ankyrin 1 (TRPA1) and its role in insulin release from rat pancreatic beta cells. PLoS One 2012; 7: e38005.

[57] Mahapatra DK, Asati V, Bharti SK. Chalcones and their therapeutic targets for the management of diabetes: Structural and pharmacological perspectives. Eur J Med Chem 2015; 92: 839-65.

[58] Liu Z, Tang L, Zou P, et al. Synthesis and biological evaluation of allylated and prenylated mono-carbonyl analogs of curcumin as anti-inflammatory agents. Eur J Med Chem 2014; 74: 671-82.

[59] Corvol JC, Klebe S, Vidailhet M, et al. Composition for use in the treatment of neurodegenerative diseases with parkinsonian syndromes. WO2013139931. 